\title{
Divisa-chave, elasticidade, liquidez internacional e autonomia de política econômica no Sistema Monetário Internacional *
}

\author{
Adriano Vilela Sampaio ** \\ Maurício Andrade Weiss ***
}

\begin{abstract}
Resumo
A autonomia de política econômica dos países no sistema monetário internacional (SMI) foi uma preocupação fundamental de Keynes nos acordos que deram origem ao regime de Bretton Woods e ainda é objeto de grande interesse na economia internacional. Neste artigo é feita uma análise entre a autonomia de política econômica e um dos componentes do SMI, a divisa-chave. Mais especificamente, buscou-se analisar dois elementos relacionados à divisa-chave, quais sejam, a elasticidade do sistema e a liquidez internacional. É defendido aqui que em um sistema mais elástico, em que a liquidez internacional não seja restringida, seria possível reduzir a assimetria entre os países de moeda conversível e inconversível. Para isso é fundamental que tais variáveis (elasticidade e liquidez) sejam passíveis de serem administradas por instituições internacionais ou por mecanismos de cooperação. Ademais, tratouse das implicações políticas advindas de sistemas em que os países tenham maior ou menor autonomia.
\end{abstract}

Palavras-chave: Sistema monetário internacional; Divisa-chave; Autonomia de política econômica; Liquidez internacional; Hierarquia monetária.

\section{Abstract}

Key currency, elasticity, international liquidity and economic policy autonomy on the international monetary system

Economic policy autonomy of the countries comprising the international monetary system (IMS) was a central concern in Keynes' proposals on the Bretton Woods Agreements and is still the object of research in the field of international economy. In this paper, an analysis is carried out between autonomy of political economy and one of the central elements of the IMS, i.e., the key currency. More specifically, it sought to analyze two elements related to the key currency, the elasticity of the system and the international liquidity. It is argued here that in a more elastic system and one in which the international liquidity is not restricted, it would be possible to reduce the asymmetry between peripheral and central countries. In order to achieve such a goal, it is necessary that such variables (elasticity and liquidity) remain under the management of policy makers. Moreover, possible political implications originating from systems in which countries have higher or lower autonomy were analyzed.

Keywords: International Monetary System; Key currency; Economic policy autonomy; International liquidity; Hierarchy of currencies.

JEL E42, F33, F55.

* Artigo recebido em 12 de dezembro de 2014 e aprovado em 18 de dezembro de 2017.

** Professor Adjunto do Departamento de Economia de Campos da Universidade Federal Fluminense (UFF), Niterói, RJ, Brasil. E-mail: adrianovs@id.uff.br.

${ }^{* * *}$ Professor Adjunto A do Departamento de Economia e Relações Internacionais da Universidade Federal do Rio Grande do Sul, Porto Alegre, RS, Brasil. E-mail: mauricio.weiss@ufrgs.br. 


\section{Introdução}

A relação entre os componentes do sistema monetário internacional (SMI) e a autonomia de política econômica (doravante autonomia) é um tema de grande interesse na economia. Para Prates (2002, p. 68), os componentes fundamentais do SMI, e que moldam o sistema financeiro internacional, são a forma da divisa-chave, o regime cambial e o grau de mobilidade de capitais. Segundo a autora, diferentes combinações desses elementos condicionariam o grau de autonomia dos países. Além desses elementos, as instituições internacionais também devem ser incluídas como componente fundamental do SMI, uma vez que podem afetar o seu funcionamento e desempenhar papel importante nas discussões, recomendações e coordenação de políticas. Além disso, podem atuar diretamente na gestão de crises cambiais e em programas de ajuste do balanço de pagamento dos países, como faz o Fundo Monetário Internacional (FMI) desde sua criação.

Segundo Guillaumin e Plihon (2008, apud De Conti, 2011, p. 12), as três principais funções do SMI são: i) garantir o intercâmbio e a circulação das moedas em âmbito internacional, de acordo com os regimes cambiais e as regras de convertibilidade das moedas; ii) permitir o ajuste dos balanços de pagamentos, especialmente o financiamento dos desequilíbrios externos; e iii) assegurar a liquidez internacional, qual seja, fornecer a moeda necessária para os intercâmbios internacionais de bens, serviços e capitais. De forma semelhante, Cohen (2013) enumera quatro elementos centrais da governança monetária global: ajustamento, liquidez, confiança e liderança. A partir desse entendimento, é analisada a relação entre autonomia e divisa-chave, mais especificamente dois elementos derivados da última, a liquidez e a elasticidade internacionais. Dessa forma, busca-se contribuir para a discussão indo

além do caráter conversível e não conversível das moedas ${ }^{1}$, tratando também de temas como ajustamento e liquidez.

A seção 1 tem como objetivo mostrar de forma sucinta a relação entre regimes cambiais, mobilidade de capitais e autonomia. Já a seção 2 faz o mesmo para as instituições internacionais. Na seção 3 é feita uma análise entre a forma da divisa-chave e autonomia, objetivo central deste artigo, bem como das diferentes maneiras pelas quais os países de moedas conversível e inconversível têm sua autonomia restringida pelos componentes do sistema. A seção 4 busca, a partir dos aspectos levantados na seções anteriores, tratar da importância da autonomia de política econômica e os seus condicionantes para os diferentes agentes e orientações do SMI. Por último, são feitas considerações finais.

\section{Taxa de câmbio, mobilidade de capitais e autonomia}

Todo país enfrenta restrições na implementação das políticas econômicas desejadas, tanto no plano doméstico como no internacional. Internamente, a restrição vem de setores da sociedade civil organizada, grupos de interesse e, mais diretamente, das articulações políticas

(1) A definição de moeda conversível e inconversível é feita na seção 3. 
a que todo governo está sujeito. No plano internacional, Sampaio (2014) define a autonomia em duas dimensões: em relação a outros países e em relação ao mercado financeiro internacional (MFI), o qual abrange tanto o mercado de capitais (investidores institucionais, fundos de investimento, etc.) quanto o mercado de crédito bancário. No primeiro caso, por meio de suas relações multilaterais, como a participação em instituições internacionais e em mecanismos de cooperação, o país se compromete a gerenciar sua política econômica respeitando as regras que escolheu seguir e que foram acordadas entre Estados soberanos ${ }^{2}$. Já a autonomia em relação ao MFI refere-se à capacidade dos governos colocarem em prática as políticas econômicas desejadas sem que a reação do MFI a elas (neste caso, os movimentos dos fluxos de capitais) seja um fator de constrangimento.

Como exemplo de restrição do primeiro caso pode-se citar as restrições de política econômica impostas pelo FMI aos países que necessitem recorrer ao seu auxílio financeiro nos momentos de constrangimento do balanço de pagamentos. Já em relação ao MFI pode-se mencionar um aumento na taxa de juros visando reduzir a inflação via redução da demanda que poderia, por exemplo, atrair capitais externos ao país, levando a uma apreciação indesejada da moeda doméstica. O último efeito pode ser considerado um constrangimento provocado pelos movimentos de capitais, uma vez que gera um efeito indesejado que poderia levar até mesmo à reversão da primeira medida.

Em ambos os casos (países e MFI), a restrição à autonomia pode ser uma estratégia voluntária, ou seja, fruto de uma decisão do próprio país de fazer parte de um mecanismo de cooperação ou de abrir sua economia aos fluxos internacionais de capitais. No entanto, tais decisões podem também ser fruto de compromissos assumidos como contrapartida a outros acordos (proteção militar, empréstimos, etc.) e de pressões tanto externas (de outros países e/ou grupos de interesse externos) como dos próprios setores domésticos.

O exemplo de restrição à autonomia mais disseminado na literatura é o modelo Mundell-Fleming, que relaciona autonomia de política monetária, grau de mobilidade de capitais e regime cambial. Tal relação é ilustrada pela chamada trindade impossível ou trilema de política econômica. Segundo o trilema, haveria um trade-off entre taxas estáveis de câmbio, livre mobilidade de capitais e autonomia de política monetária. Com câmbio flutuante e livre mobilidade de capitais a estabilidade do câmbio seria perdida; com câmbio fixo e livre movimentação de capitais perder-se-ia a autonomia de política monetária; e com câmbio fixo e controles de capitais (o que restauraria a autonomia de política) a livre movimentação de capitais seria sacrificada (Bradford, 2005) .

(2) Tal restrição pode, evidentemente, ir muito além da política econômica, estendendo-se a questões militares, ambientais, migratórias, direitos de propriedade, não desenvolvimento de tecnologia nuclear, etc.

(3) No caso da política fiscal, de acordo com Mundell (1963), a política fiscal seria mais eficaz com maior mobilidade de capitais em regimes de câmbio fixo. Já sob câmbio flutuante, ocorreria o contrário, qual seja, quanto maior a mobilidade, menor a eficácia da política fiscal. 
Sobre o trilema, Mendonça e Pires (2006), argumentam que de acordo com a equação da paridade descoberta da taxa de juros, há um nível desta taxa que é consistente com o equilíbrio externo, cuja determinação foge do raio dos formuladores de política. Além disso, caso o governo não siga as políticas que o mercado considera responsáveis, este fica sujeito a penalidades, sob a forma de depreciação da moeda - se o câmbio for flutuante - ou perda de reservas - em caso de câmbio fixo (ou administrado) -. Os agentes passam, então, a ser "físcais" da política econômica dos países e, dessa forma, medidas que coloquem em dúvida a previsibilidade, a rentabilidade ou a liquidez dos investimentos, podem ser "punidas" com fugas de capitais.

Considerando o atual SMI, dadas as facilidades técnicas e legais para a rápida movimentação de recursos e o comportamento mimético (refletido em fenômenos como efeito manada, profecias autorrealizáveis e efeito contágio ${ }^{4}$ ) dos agentes em suas decisões de alocação de recursos, os fluxos de capitais se tornaram muito voláteis. Eles podem ser facilmente aplicados nos países com maiores oportunidades de ganhos e retirados ao menor sinal de instabilidade, decisões que muitas vezes estão desvencilhadas dos "fundamentos" econômicos do país em questão.

Entretanto, com mobilidade de capitais, a autonomia da política monetária poderia ser restringida mesmo com a adoção do câmbio flutuante. Conforme aponta Tobin (1978), com livre mobilidade de capitais, os países "are not capable of adjusting to massive movements of funds (...) without significant sacrifice of the objectives of national economic policy with respect to employment, output and inflation." (Ibid, p. 154). Essa incapacidade de ajuste decorreria dos impactos que variações na taxa de câmbio podem ter sobre a economia doméstica (nível de preços, taxa de juros, equilíbrio do balanço de pagamentos, variação patrimonial do passivo em moeda estrangeira etc.) e que não podem ser ignorados pelo governo. Isso faz com que o governo tenha que intervir no mercado cambial, não permitindo que a taxa de câmbio atue como variável de ajuste.

Nessa mesma linha, Rey (2013) encontra a partir de testes empíricos uma estreita relação entre os ciclos financeiros globais e os fluxos de capitais direcionados aos países em desenvolvimento. Em momentos de reduzida incerteza e baixa aversão ao risco, esses fluxos ingressam massivamente afetando os mercados financeiros e monetários. Já nos momentos de reversão das expectativas, há uma súbita saída desses fluxos, trazendo impactos severos a esses mercados e pressionando a taxa de câmbio dos países, sendo que a política monetária do país em questão teria baixa capacidade de reverter esses movimentos. Nesse sentido, seja por conta dos potenciais efeitos negativos ou pela própria (in)capacidade do ajuste frente a grande volumes de fluxos, haveria não um trilema, mas um dilema entre a abertura financeira e a autonomia. Destarte, com mobilidade de capitais a autonomia seria sacrificada independentemente do regime cambial adotado. Ou como diz Flassbeck (2001), a trindade impossível seria na verdade uma dualidade impossível. Esta perda de autonomia decorrente de

(4) Autores como Banerjee (1992) e Calvo e Mendoza (1999) tratam dos fenômenos descritos. 
Divisa-chave, elasticidade, liquidez internacional e autonomia de política econômica no Sistema ...

abertura financeira ${ }^{5}$ se apresenta de forma ainda mais acentuada no caso de países de moeda inconversível ${ }^{6}$, como visto na seção 3.2.

\section{Instituições internacionais}

A relação entre a autonomia de política econômica e as instituições internacionais é ambígua. Por um lado, a liberdade de adoção de políticas é restringida por regras acordadas entre os países que participam de uma instituição. Ao fazer parte da Organização Mundial do Comércio (OMC), por exemplo, o país se compromete a abrir mão ou ao menos limitar a adoção de tarifas sobre importações ou de subsídios às exportações. Nesse caso, a restrição à autonomia é uma decisão de cada país e os termos de tal restrição são acordados entre os Estados soberanos, embora o poder para estabelecê-los possa ser profundamente assimétrico tanto nas instituições em que os votos sejam determinados por cotas (como o FMI) quanto naquelas em que vigora o sistema de um voto por país ${ }^{7}$ (como a OMC). Por outro lado, as instituições internacionais poderiam aumentar a autonomia vis-à-vis o MFI. Não apenas instituições formais, mas quaisquer instrumentos ou alianças entre países que facilitem a cooperação. $\mathrm{O}$ uso de controles de capitais, por exemplo, poderia ser mais eficiente quando feito por um conjunto de países. O controle de fluxos na origem e destino poderia facilitar a taxação e (quando for o caso) a supressão de certos tipos de fluxos; a harmonização da regulação poderia reduzir a chamada arbitragem regulatória; e a coordenação de políticas macroeconômicas poderia facilitar a adoção de políticas que não sejam market-friendly, uma vez que os investidores não teriam a opção de alocar sua riqueza em países que praticassem políticas diferentes das adotadas pelo conjunto de países (Gallagher, Griffith-Jones; Ocampo, 2012).

Instituições internacionais poderiam também desenvolver mecanismos de cooperação, tornando o ajuste uma tarefa conjunta, promovida por países deficitários e superavitários. Os ajustes seriam feitos não apenas pela contração nos países deficitários, mas também por políticas expansionistas ou valorização cambial nos superavitários. Com o aumento na demanda dos últimos, os primeiros poderiam promover um ajuste expansionista pelo aumento das exportações. Existem atualmente propostas dessa natureza ${ }^{8}$ e já houve outras tentativas de dividir os fardos do ajuste e também responsabilizar os países superavitários: em Bretton Woods, com o Plano Keynes, e, em 1972, nas negociações do Comitê dos 20 (C20), por sugestão da delegação estadunidense comandada por Paul Volcker (Williamson, 2011). Mas, ambas foram rejeitadas pelos principais países superavitários da época (EUA em Bretton

(5) Um ambiente de total ou alta mobilidade de capitais é entendido neste artigo como um contexto em que é permitido aos residentes manterem ativos e passivos denominados em moeda estrangeira, bem como aos não residentes o acesso ao sistema financeiro doméstico (Prates, 1999). Em outras palavras, um ambiente em que a movimentação de recursos entre os países pode ser feita sem restrições, de forma rápida e com baixos custos.

(6) A definição de moeda conversível é dada posteriormente.

(7) Uma vez que nesses casos o voto de um país pode ser influenciado por negociações em outros temas, proteção militar por exemplo.

(8) Como Davidson (1997), Williamson (2011) e Unctad (2009). 
Woods e Alemanha nas negociações do C20). A própria cláusula da moeda escassa, defendida por Keynes e aprovada em Bretton Woods, que permitia práticas protecionistas contra países cujos recorrentes superávits tornassem suas moedas escassas no FMI, foi uma forma de dividir o ônus do ajuste. Esta é uma questão política complexa, pois, se por um lado, seria benéfico não deixar o ajuste somente como responsabilidade dos países deficitários, é preciso haver limites acerca do volume e da persistência dos déficits de cada país, do contrário, os países superavitários poderiam relutar em participar do mecanismo. Ainda assim, seria um meio engenhoso de dar uma orientação mais expansionista ao sistema, já que permitiria que países deficitários promovessem o ajuste sem recorrer a políticas deflacionárias.

Ainda sobre a proposta de Keynes em Bretton Woods, o objetivo era construir um sistema em que a pressão contracionista sobre o comércio internacional exercida pelos ajustes fosse substituída por uma expansionista. Essa foi uma preocupação que pode ser vista nas diferentes versões de suas propostas. Segundo Keynes (1980/2013), os custos sociais de ajustes contracionistas são muito maiores que dos expansionistas e tais pressões acabam atingindo também os próprios países superavitários. Como opções de ajuste para os países superavitários estariam a expansão do crédito e da demanda doméstica, apreciação da moeda doméstica (ou aumento dos salários nominais), redução de tarifas e outras barreiras à importação e empréstimos internacionais para países de menor grau de desenvolvimento econômico (Ibid).

E, finalmente, a autonomia também poderia ser fortalecida caso essas instituições funcionassem como uma fonte adicional de recursos aos países para o financiamento do balanço de pagamentos, quando não houver disponibilidade de financiamento pelo MFI ou quando as condições (custo e prazo) para tal forem insatisfatórias ${ }^{9}$. Ou seja, elas podem ser importantes em contextos com ou sem livre mobilidade de capitais, mas em que prevalece um baixo volume de entrada de fluxos. As instituições internacionais podem agir como fontes mais atuantes de capitais compensatórios pela disponibilização de moedas nacionais que tenham aceitação internacional, inclusive de uma moeda própria, como o Direito Especial de Saque (DES). Tal mecanismo poderia ser uma alternativa ao financiamento pelo MFI e uma maneira mais rápida e simples que o empréstimo de moedas entre países, especialmente em momentos agudos de crises, quando os montantes requeridos são maiores e devem ser feitos de forma mais rápida.

Caso não haja uma instituição capaz de suprir essa função, ela poderia ser cumprida por mecanismos de cooperação, como acordos de swap de moedas locais, em que grupos de países se comprometem a fornecer linhas de financiamento em moeda local. Esse foi o caso da Crise Financeira Global de 2008 (a qual se transformou na Grande Recessão que perdura até os dias de hoje) quando os EUA disponibilizaram linhas de swap para diversos países, incluindo emergentes como Brasil, Cingapura, Coreia do Sul e México ${ }^{10}$. Segundo James

(9) Por dizer respeito também a mecanismos de financiamento do balanço de pagamentos, esse aspecto da relação entre instituições internacionais e autonomia também é abordado na seção 4.

(10) Ver: http://www.federalreserve.gov/newsevents/press/monetary/20081029b.htm. 
(2013), o longo tempo decorrido da última grande crise internacional (1929) havia reduzido a percepção acerca da importância da cooperação e coordenação de políticas, mas no imediato pós-crise (até 2009) a cooperação via linhas de swap atingiu volumes sem precedentes e foram efetivas em mitigar a instabilidade financeira e lidar com a baixa liquidez internacional prevalecente, embora o mesmo não tenha ocorrido no período 2010-2012. Outra saída plurilateral seria a criação de fundos conjuntos de reserva para socorrer países com problemas de liquidez, como o da Associação de Nações do Sudeste Asiático ${ }^{11}$ (Ansea), e o dos BRICS ${ }^{12}$, criado em julho de 2014 com um montante de US\$100 bilhões.

Essa atuação de instituições ou grupos poderia fortalecer o caráter cooperativo/público - em detrimento do privado - do ajuste e do financiamento do BP. Nesse caso, os recursos disponíveis aos países para o financiamento do BP não dependerão apenas da disposição dos mercados privados. Em outras palavras, os agentes privados perdem poder no sistema vis-à-vis os públicos, o que pode aumentar o grau de autonomia em relação a esses mercados. Dessa forma, os formuladores de política poderiam ter mais liberdade, uma vez que uma possível fuga de capitais em resposta a determinadas políticas poderia ser compensada com recursos advindos de instituições ou de acordos de cooperação. Além disso, sabedores de que os países em problemas têm instituições de suporte, movimentos de manada por conta de temores de grandes desvalorizações poderiam ser reduzidos.

No entanto, esse fortalecimento da autonomia dependerá da existência de condicionalidades para acessar os recursos e, mais especificamente, da natureza de tais condicionalidades. Se os critérios forem similares aos usados pelos investidores privados ao decidirem investir ou não em um país, então o aumento na autonomia será mais modesto. Tomando novamente o fundo dos BRICS como exemplo, 70\% dos recursos disponíveis estão condicionados a um acordo do país solicitante com o FMI, o que mostra que, pelo menos em seus primeiros anos, tal fundo não será um instrumento de suporte de natureza muito diferente do prevalecente.

Foi visto, portanto, que apesar de em alguma forma limitar a autonomia, no geral as instituições poderiam aumentá-la, desde que isso fosse um objetivo e que fossem desenvolvidos os instrumentos adequados para tal fim.

\section{Autonomia e divisa-chave}

Nas duas seções anteriores objetivou-se discutir como regras e instituições do SMI são elementos condicionantes à autonomia de política econômica. Um aspecto ainda não discutido refere-se à forma da divisa-chave, a qual, segundo Prates (2002), é um dos componentes fundamentais do SMI. De forma a sustentar tal afirmação, faz-se necessário mostrar como esse componente condiciona aspectos centrais do SMI, como elasticidade e liquidez internacional. A presente seção busca esclarecer a centralidade da divisa-chave para a análise do SMI.

(11) Em 2014 o fundo contava com US\$240 bilhões em reservas.

(12) Grupo composto por Brasil, Rússia, Índia, China e mais recentemente África do Sul. 
Embora fosse possível tratar desse aspecto juntamente com a questão da mobilidade dos fluxos de capitais e do regime cambial, dado suas características complementares, optou-se por manter uma seção à parte, pois se trata do objetivo central desse artigo.

\subsection{A divisa-chave}

Divisa-chave é definida aqui como o ativo que desempenha as funções clássicas da moeda (unidade de conta, meio de pagamento e reserva de valor) no plano internacional. Em um país, a moeda nacional (emitida pelo Estado) é o ativo mais líquido. O Estado tem meios (coercitivos inclusive) para fazer com que sua moeda cumpra suas funções e seja efetivamente o ativo líquido por excelência ${ }^{13}$. Ou seja, no plano doméstico a moeda nacional é moeda de jure e de facto. No plano internacional, nunca houve uma moeda internacional em sentido pleno, i.e., que fosse emitida não por um país e sim por uma instituição supranacional. O que há de mais próximo atualmente é o DES. Historicamente tal função sempre foi desempenhada pela moeda doméstica de maior aceitação internacional. No entanto, o uso de uma moeda doméstica como divisa-chave não decorre de uma imposição legal, já que em um ambiente de Estados soberanos sem uma autoridade central, a capacidade de um país impor sua moeda como moeda internacional é, no mínimo, limitada. Ou seja, diferentemente do que ocorre no plano doméstico, um ativo não se torna moeda (divisa-chave neste caso) por ter sido definido legalmente como tal, e sim por exercer as funções de moeda de facto (embora não de jure). Portanto, se a divisa-chave é o ativo capaz de cumprir a função de moeda no plano global, ela será, necessariamente, o ativo mais líquido da economia internacional.

A importância da divisa-chave para o SMI e o seu tratamento como um de seus componentes fundamentais, tem que ser entendida num contexto mais geral, qual seja, da importância da moeda para a economia capitalista. A moeda desempenha três funções em uma economia de tal natureza: unidade de conta, meio de pagamento e reserva de valor. A moeda como meio de pagamento elimina a necessidade de trocas diretas (escambo) e como unidade de conta permite que os preços e contratos sejam denominados em uma mesma referência de valor $^{14}$. Assim como na esfera doméstica, na internacional o uso de uma ou poucas moedas também serve como um facilitador para as transações internacionais. Em uma economia monetária de produção (em contraposição a uma economia de salários reais ou de trocas/mercantilista), a moeda, além de meio de troca, tem a função de reserva de valor (Keynes, 1978). Por ser o ativo mais líquido da economia, é nessa forma de riqueza que os agentes vão manter sua riqueza em momentos de grande incerteza. "O rompimento do estado de confiança faz recair de uma forma absoluta sobre o dinheiro a esperança de preservação do valor da riqueza" (Belluzzo; Almeida, 2002; p. 77). Nesse sentido, seguem os autores, os agentes buscam uma forma de riqueza que não possa ser contestada, que seja socialmente

(13) Salvo casos de hiperinflação, instabilidade política, etc.

(14) Para Keynes (1930/2013, p. 3), as propriedades de meio de pagamento e reserva de valor de um ativo derivariam de sua utilização como unidade de conta, uma vez que primeiramente os preços e contratos têm de ser expressos em termos dessa unidade. 
aceita. Enquanto em um país a moeda nacional (emitida pelo Estado) é o ativo mais líquido, no plano internacional tal papel é desempenhado pela divisa-chave. Sendo a divisa-chave, por definição, o ativo mais líquido da economia internacional, ela será o ativo mais desejado e é nela que os agentes buscarão manter seus estoques de riqueza, funcionando como um "porto seguro" para os investidores ${ }^{15}$.

Seja a divisa-chave uma moeda internacional ou uma moeda doméstica, o SMI pode ter outras moedas domésticas que exerçam, em menor grau que a divisa-chave, as funções da moeda no plano internacional. Prates (2002) define essas moedas como moedas conversíveis. $\mathrm{O}$ conceito definido pela autora não se refere somente à possibilidade legal de conversão (conversibilidade de jure), mas também à conversibilidade de facto. Neste artigo o conceito é usado nesse mesmo sentido. Em contraposição às moedas conversíveis, há as inconversíveis, ou seja, aquelas que não desempenham, nem mesmo parcialmente, as funções da moeda em âmbito internacional e cuja aceitação seja restrita ao país emissor.

O DES não é uma moeda nem uma obrigação do FMI; seu valor é baseado em uma cesta de moedas (dólar estadunidense, iene, euro, libra e renminbi) e seu uso é restrito aos bancos centrais, ou seja, não pode ser utilizado por entes privados. Dessa forma, pela definição adotada neste trabalho, o DES não se configura como divisa-chave, mas como uma moeda conversível, pois, pelo menos parcialmente, exerceria as funções da moeda no plano internacional.

Aqui as moedas conversíveis serão tratadas também como "moedas centrais" e as demais como "periféricas", com a mesma denominação se aplicando aos países que as emitem. Ou seja, aqueles que emitem moedas conversíveis são chamados de centrais e os demais de periféricos. É importante reiterar que tais denominações para os países referem-se somente ao tipo de moeda emitida. Nesse sentido, embora deva ser compreendido de forma análoga ao utilizado tradicionalmente, não possui relação direta com tal conceito, ou seja, com o nível de renda e/ou de desenvolvimento. Um país desenvolvido (no sentido tradicional) pode, portanto, ser um país "periférico" quando se trata do uso internacional de sua moeda.

\subsection{Forma da divisa-chave}

Quando o papel de divisa-chave é exercido por uma moeda doméstica, é preciso considerar as dimensões hierárquica e assimétrica que o sistema assume e que terão implicações para a autonomia de política econômica.

(15) “Apesar de não serem sinônimos, os conceitos de liquidez e conversibilidade são complementares. Liquidez pode ser entendida como a capacidade de um ativo ser convertido em moeda, o ativo líquido por excelência. Já conversibilidade é a aptidão de um ativo exercer em âmbito internacional as funções clássicas da moeda. Ou seja, retomando ao discutido no parágrafo acima, como no âmbito internacional as moedas legais de cada país não são meios de pagamentos de jure, apenas moedas conversíveis deixam de ser meramente ativos e passam a desempenhar o papel de moeda nesse âmbito. É nesse sentido que moedas conversíveis são as mais líquidas na esfera internacional”. 
Segundo Prates (2002), a primeira dimensão resulta da aceitação de uma moeda nacional como divisa-chave. A partir da moeda com maior aceitação - a divisa-chave - as moedas podem ser hierarquizadas de acordo com os prêmios de risco exigidos pelos agentes para abrir mão da divisa-chave (livre de risco). Nessa hierarquia, abaixo da divisa-chave situam-se outras moedas conversíveis e, em seguida, as inconversíveis (Belluzzo; Carneiro, 2004). Na abordagem de Cohen (2004), a hierarquia toma a forma de uma pirâmide com algumas poucas moedas fortes no topo e uma ampla base de moedas fracas.

A segunda dimensão (assimetria) é uma implicação da primeira (hierarquia). De acordo com o grau de aceitação internacional de sua moeda (de sua posição na hierarquia), um país terá mais ou menos autonomia. Na definição da taxa de juros, por exemplo, uma vez que a divisa-chave não tem prêmio de risco, o país emissor define a taxa de juros básica do sistema e os demais definem suas taxas a partir desse patamar.

Em um SMI em que vigora a hierarquia de moedas, os países de moeda conversível têm maiores condições de financiar o balanço de pagamentos em suas próprias moedas, uma vez que estas possuem liquidez (ou seja, os riscos de sua posse são reduzidos pela existência de mercados amplos, líquidos e profundos onde podem ser negociadas) e, por isso, têm maior aceitação pelos agentes. Da mesma forma, quanto mais baixa a posição na hierarquia de moedas, maiores serão as restrições ao financiamento do balanço de pagamentos na própria moeda. É exatamente dessa dimensão que a abordagem do pecado original (original sin) trata, qual seja, a incapacidade de um país de emitir dívidas no mercado internacional denominada em sua própria moeda (Eichengreen; Hausmann; Panizza, 2003).

Sendo assim, a autonomia de cada país está diretamente relacionada à sua posição na hierarquia de moedas. Dado que as moedas conversíveis são ativos mais líquidos que as inconversíveis, elas são uma forma mais segura de se manter a riqueza e, por isso, a demanda pelas primeiras varia menos que pelas últimas. Nesse sentido, países detentores de moedas conversíveis teriam maior grau de autonomia e os países periféricos estariam sujeitos a maiores constrangimentos às suas políticas econômicas.

Ao realçar a importância do poderio financeiro para determinar a maior ou menor liberdade de execução das políticas monetárias, Keynes ${ }^{16}$ estava apontando para a hierarquia entre as moedas nacionais. Pretendia sublinhar a capacidade inferior das economias devedoras e "dependentes" de atrair recursos "livres" para a aquisição de ativos e bens denominados na moeda nacional. Dessa diferença de poder financeiro nascem importantes assimetrias, nos processos de ajustamento de balanço de pagamentos, entre países credores e devedores (Belluzzo, 2000, p. 97).

Sendo a divisa-chave uma moeda nacional, a hierarquia é aprofundada, aumentando a assimetria e proporcionando ao país emissor o maior grau de autonomia dentre todos os países. $\mathrm{O}$ país que emite a divisa-chave será aquele (e talvez o único) que financia o balanço de

(16) O autor se refere ao Treatise on Money. 
Divisa-chave, elasticidade, liquidez internacional e autonomia de política econômica no Sistema ...

pagamentos em sua própria moeda, uma vez que ela será o ativo de maior liquidez do sistema. Ademais, como afirma Serrano (2002), se a moeda é puramente fiduciária a restrição é praticamente inexistente, uma vez que não haveria mais o risco de fuga para o ouro e que seria possível atrair qualquer volume de capitais.

A relação entre a divisa-chave e autonomia deve levar em conta também a forma pela qual a divisa-chave é criada e disponibilizada no SMI. Para isso, é necessário analisar as relações entre liquidez internacional, elasticidade e divisa-chave, para assim entender de que forma diferentes configurações do SMI constrangem os países no processo de busca pelo equilíbrio externo.

\subsection{Liquidez internacional e elasticidade}

Liquidez internacional é entendida aqui como a oferta da divisa-chave no sistema monetário e financeiro internacional em suas diferentes formas (o próprio papel moeda e ativos financeiros nela denominados). A importância da liquidez internacional está ligada à relevância da moeda para o funcionamento eficiente do SMI. Como mencionado anteriormente, uma das funções do SMI é prover a liquidez internacional, i.e., o volume de moeda necessário para os intercâmbios internacionais de bens, serviços e capitais. É preciso que haja oferta de divisachave no sistema para que não se restrinja o crescimento do comércio e investimentos internacionais, para satisfazer as necessidades de financiamento do balanço de pagamentos de países que não emitem a divisa-chave ${ }^{17}$ e para que os investidores tenham um meio seguro e estável de manter sua riqueza ${ }^{18}$.

Além de estar diretamente relacionada à forma da divisa-chave e ao grau de mobilidade de capitais (como destacado adiante), a liquidez internacional também pode ser condicionada pela elasticidade do sistema. A elasticidade do sistema monetário e financeiro internacional é definida aqui como em Borio e Disyatat (2011, p. 24): "the degree to which the monetary and financial regimes constrain the credit creation process, and the availability of external funding more generally" ou, de forma geral, como a capacidade de criação de liquidez internacional pelo regime monetário e financeiro vigente. Adaptando essa definição aos conceitos aqui utilizados, pode-se dizer que a elasticidade do SMI se refere à capacidade de criação de divisachave. Tal capacidade seria uma característica estrutural ou institucional. Dependendo da regulação e da institucionalidade a que o sistema financeiro do país emissor da divisa-chave doméstico estiver submetido, ele terá maior ou menor capacidade de prover a divisa-chave ${ }^{19}$.

(17) Vale notar que mesmo havendo oferta, não significa que todos os países que necessitarem de recursos terão suas demandas atendidas. $\mathrm{O}$ acesso dos diferentes países a essa oferta dependerá também de fatores domésticos concernentes a cada um deles.

(18) Sobre este último aspecto, Arrighi (1994) destaca a importância dos sistemas de dívida pública como forma de transformar dinheiro em capital sem os riscos dos investimentos produtivos e na forma de ativos líquidos.

(19) É importante destacar que a criação de crédito denominado na divisa-chave pode se dar também em outros países, como é o caso atualmente de centros offshore (como a city londrina) que são capazes de criar crédito denominado em dólar. Nesses casos, a liquidez internacional estaria condicionada pela institucionalidade de todos os sistemas financeiros capazes de criar divisachave. 
Sobre a relação entre a institucionalidade e regulação do sistema financeiro e elasticidade, Guttmann (1996, p. 53) aponta que nos sistemas financeiros domésticos a passagem da moeda-mercadoria (lastreada em ouro) para a moeda creditícia após a década de 1930 fez com que a emissão monetária se livrasse da "limitação metálica" e passasse a ser condicionada pela expansão do crédito no sistema bancário. "Essa transformação da moeda, de uma base mercantil em uma relação de crédito, assegurou-nos uma oferta monetária elástica que pudesse reagir à necessidade de liquidez e de financiamento em vigor em qualquer dado momento da economia" (Ibid, p. 54). Tal raciocínio se baseia no conceito de moeda endógena, em que a criação de crédito não depende do nível de reservas bancárias ${ }^{20}$, ou de forma, mais geral, à ideia keynesiana de que o financiamento do investimento não depende de saldos prévios de poupança. "(...) the theory of endogenous money was being put forward by Post Keynesians (...) to shift attention to bank credit as the causal force, bank reserves being at the end of the causal chain" (Dow, 2001, p. 158).

A ideia acima se refere aos sistemas financeiros domésticos, mas tal raciocínio pode ser trazido para a esfera internacional. Da mesma forma que o crédito não depende da poupança em sistemas financeiros domésticos, no plano internacional o fim da conversibilidade dólarouro a partir de 1971 permitiu a desvinculação entre poupança e crédito, de forma que a capacidade de financiamento do balanço de pagamentos de países deficitários não estaria mais condicionada à atração de poupança dos superavitários. Como aponta Dow (2001, p. 157), desde a década de 1970, com o fim do regime de Bretton Woods, a provisão de liquidez passou a ser feita cada vez mais pelo sistema financeiro internacional (SFI) e menos pela cooperação entre as autoridades monetárias nacionais e entre estas e o FMI, ou seja, mais pelo SFI que pelo SMI. Essa predominância do SFI também é destacada por Borio e Disyatat (2011) em sua crítica teórica e empírica ao diagnóstico que coloca o excesso de poupança global (saving glut) como uma das causas da Grande Recessão. De acordo com o autor, ao se analisar somente os fluxos líquidos dos EUA (deficitário) com o resto do mundo, não é possível distinguir a origem dos investimentos em títulos privados estadunidenses a partir de agentes privados e entes públicos de países emergentes superavitários. No entanto, pela análise dos fluxos brutos de capitais feita pelos autores, depreende-se que a maior parte dos fluxos se origina de agentes privados europeus, com destaque aos bancos que operavam na Inglaterra, país igualmente deficitário. A maior origem de fluxos desse país indicaria a criação de crédito pelos bancos estadunidenses na city londrina. Pressupor, portanto, que a disponibilidade de fluxos de capitais para o financiamento do balanço de pagamentos de um país dependa da disposição de agentes superavitários em financiá-los, tal como pressupõe a abordagem do saving glut, seria o mesmo que pressupor que bancos são instituições que simplesmente transferem recursos de agentes poupadores para devedores.

A elasticidade do SMI definiria o potencial de liquidez do sistema. Um sistema com maior elasticidade pode criar mais liquidez que um de menor elasticidade, mas isso não

(20) Ver Wray (2001). 
significa que a liquidez será sempre alta em um sistema de alta elasticidade. Poderia haver capacidade de criação de liquidez sem que ela de fato ocorra, da mesma forma que em um sistema financeiro doméstico há momentos de contração de crédito. Nesse sentido, uma maior elasticidade pode implicar também maior amplitude de ciclos de liquidez internacional, principalmente se considerarmos que os sistemas financeiros podem adquirir um caráter prócíclico, que torna mais intensas tanto as expansões em períodos de otimismo quanto as contrações em período de pessimismo. Acentuadas e rápidas oscilações na liquidez internacional, por sua vez, poderiam levar a processos de formação de bolhas financeiras e posteriores crises de balanço de pagamentos.

A alternância de momentos de alta e baixa liquidez internacional no sistema pode ser explicada a partir do conceito de preferência pela liquidez, definida por Keynes (1996, p. 174) como a proporção de recursos (em termos monetários) que o detentor de riqueza deseja manter sob a forma de moeda (a forma líquida por excelência) em diferentes circunstâncias. A decisão de manter recursos sob a forma líquida envolve duas decisões: a primeira é entre consumir ou não consumir e a segunda é entre manter a riqueza em ativos com maior ou menor grau de liquidez. Como o autor ressalta, a preferência pela liquidez não está relacionada à primeira decisão, mas à segunda, ou seja, à circulação da riqueza ${ }^{21}$. Em determinados momentos, o detentor de riqueza desejará manter parte de seus recursos na forma de ativos mais líquidos, abrindo mão dos rendimentos que a posse de outros ativos financeiros poderia gerar. Tal comportamento, segue o autor, só se explicaria pela existência da incerteza, que faz com que o agente prefira a segurança ao rendimento ${ }^{22}$.

Segundo Dow (2001), no âmbito internacional, em momentos em que a preferência pela liquidez dos agentes privados se acirra, estes buscam a divisa-chave ${ }^{23}$ ou ativos nela denominados, enquanto as posições em moedas nos patamares mais baixos da hierarquia seriam desfeitas. Portanto, quando há alta preferência pela liquidez, a liquidez internacional será baixa mesmo em sistemas em que a elasticidade é alta, ou, em outras palavras, a liquidez internacional ficaria abaixo de seu potencial, pois há uma drenagem para o sistema financeiro do país emissor da divisa-chave. Tal movimento poderia levar a uma redução do crédito de diferentes maturidades e moedas e elevação das taxas de juros, tornando mais difícil o equacionamento do balanço de pagamentos por fluxos de capitais privados. Na situação oposta, de baixa preferência pela liquidez, os detentores de riqueza aceitam deter ativos de menor liquidez em busca de maiores rendimentos, processo conhecidos como search for yield ou, como denominado por Minsky, money chasing yield (Coutinho; Belluzzo, 1996), ampliando o

(21) Ou circulação financeira em contraposição à circulação industrial ou de renda conforme a separação feita no capítulo 15 de Keynes (1930/2013).

(22) Segundo Davidson (1998), a incerteza que envolve as recompensas futuras presente na análise de Keynes não equivale ao risco probabilístico, mas a uma situação em que não haveria uma trajetória de longo prazo que pudesse ser prevista e que fosse baseada nos fundamentos da economia, o que ele define como um sistema não ergódico.

(23) Ou, nos termos da autora, a moeda internacional (international money). 
mercado destes. Podemos, portanto, associar alta preferência pela liquidez à baixa liquidez internacional e vice-versa.

Retomando à questão da assimetria do ajuste do balanço de pagamentos, por ocuparem uma posição inferior na hierarquia de moedas, os fluxos de capitais para países de moeda inconversível dependeriam, em última instancia, da liquidez internacional, sendo, portanto, mais voláteis (Biancarelli, 2007). Consequentemente, esses países seriam mais vulneráveis a mudanças nas fases desses ciclos, pois seus ativos seriam rapidamente vendidos nos movimentos de fuga para qualidade, que se traduzem em aumento da demanda por ativos considerados mais seguros, principalmente os títulos do Tesouro estadunidense. Como resultado, haveria desvalorização das moedas inconversíveis e valorização das conversíveis. Além do mais, a liquidez e o tamanho reduzido dos mercados cambiais e financeiros dos países periféricos em relação à dimensão dos fluxos de capitais os tornariam mais vulneráveis à volatilidade desses fluxos (Prates, 2002).

A instabilidade a que os países periféricos estão sujeitos se acirra ainda mais com a prevalência de alta mobilidade de capitais. Para Farhi (2006), nesse contexto, os canais de transmissão dos ciclos internacionais de liquidez para a economia doméstica dos países periféricos ampliam-se, aumentando a volatilidade de suas principais variáveis financeiras, cujas trajetórias dependerão ainda mais das decisões dos investidores estrangeiros. Takáts e Vela (2014) apontam que as flutuações do apetite por risco dos investidores estão relacionadas à política monetária das economias avançadas e que a abertura financeira dos países emergentes fez com que tais flutuações se traduzissem em maior volatilidade macroeconômica nesses países $^{24}$. As evidências empíricas indicariam isso mesmo para países que adotam regime de flutuação cambial pura.

Segundo Carneiro (2003, 2008), uma das principais consequências da abertura financeira em países de moeda inconversível é que o processo de ajustamento do balanço de pagamentos será sempre mais perverso que nos países de moeda conversível, uma vez que, mesmo com grandes variações, a taxa de câmbio não seria capaz de isolar a política monetária. Por se tratar de moedas inconversíveis, não haveria movimentos de especulação estabilizadora e sim pró-cíclicos ${ }^{25}$. Por isso, o ajustamento passaria sempre pela taxa de juros. Este problema se acentua em um contexto de alta mobilidade de capitais, como o atual. Isso ocorre porque a instabilidade externa da moeda pode se transmitir mais facilmente para o plano doméstico, traduzindo-se em uma maior instabilidade da taxa de juros interna.

(24) Os autores investigaram a influência da política monetária dos países avançados sobre as taxas de juros (de curto e longo prazo), taxa de câmbio, crédito bancário internacional e fluxos de portfólio para um conjunto de vinte e cinco países emergentes.

(25) Se houvesse movimentos de especulação estabilizadora, a desvalorização cambial (que equivale a uma redução do preço da moeda doméstica em relação à moeda em que ela é cotada) faria com que esses ativos (moedas periféricas) se tornassem atraentes como opção de investimento, o que reverteria o movimento de desvalorização. O caráter pró-cíclico decorre do fato de que em momento de alta preferência pela liquidez, a depreciação cambial reforça o desejo dos investidores por ativos mais seguros, acentuando o processo de fuga das moedas periféricas. 
Divisa-chave, elasticidade, liquidez internacional e autonomia de política econômica no Sistema ...

Dessa perspectiva, a inconversibilidade seria uma característica permanente dos países periféricos, perpassando as várias ordens monetário-financeiras internacionais e assumindo maior ou menor importância de acordo com o grau de liberalização dos fluxos de capitais (Carneiro, 2008, p. 543).

\subsection{Forma da divisa-chave e a liquidez internacional}

A importância da divisa-chave para o SMI, também se mostra na sua relação com a liquidez internacional. Mais especificamente, a forma da divisa-chave tem papel central na análise porque é um dos condicionantes da liquidez do sistema. Com a divisa-chave lastreada em ouro, a liquidez internacional dependerá, em algum grau, dos estoques e da nova produção do metal. Mesmo que as transações do sistema não fossem liquidadas em ouro e os países membros aceitassem manter moedas conversíveis como reservas internacionais, como ocorria no padrão ouro-libra e no ouro-dólar, o ouro ainda representaria um constrangimento.

Foi com o objetivo de permitir um melhor controle sobre uma variável tão importante como a liquidez internacional que, mesmo antes dos acordos de Bretton Woods, houve tentativas de reduzir o uso do ouro no sistema. Já na Conferência de Gênova em 1922 houve propostas para a coordenação da demanda de ouro pelos bancos centrais e para a redução do uso do ouro no sistema, com moedas nacionais "fortes" que complementassem as reservas (Fed, 1922; Fink, 1984). Em 1936, com o Acordo Monetário Tripartite firmado pela Inglaterra, EUA e França, foi assinado o Gold Agreement Act, em que os países se comprometeram a realizar consultas diárias sobre a taxa desejada e sustentá-las por meio da compra e venda de divisas no mercado (Eichengreen, 1985). A partir daí, a intenção existente em Gênova de centralização e coordenação da demanda de ouro pelos bancos centrais tornou-se realidade, com as transações internacionais sendo limitadas aos bancos centrais e a fundos de estabilização e com restrições ao uso doméstico do metal (Ibid).

No caso da divisa-chave ser uma moeda nacional lastreada em ouro, a liquidez internacional dependeria não apenas da criação de moeda (e outros ativos denominados na divisa-chave) pelo país emissor, mas também da forma como ela é introduzida no SMI, o que ocorre pela geração de déficits no balanço de pagamentos. Se houver baixa ou nula mobilidade de capitais, o único canal de suprimento da divisa-chave seriam os déficits em transações correntes do país emissor da divisa-chave. Caso haja livre mobilidade de capitais, a divisachave também será suprida pela exportação de capitais, via conta financeira.

Assim, o constrangimento à liquidez poderia vir não apenas da quantidade de ouro existente no sistema, mas também das políticas dos países detentores de grandes estoques de ouro. Eichengreen e Flandreau (2009), por exemplo, argumentam que a baixa liquidez internacional no entreguerras foi resultado não de uma suposta insuficiência de estoques de ouro, mas das políticas de seus maiores detentores, EUA e França. Estes países, segue o autor, esterilizavam as entradas de ouro e não deixavam a liquidez doméstica crescer, o que impedia que esse ouro voltasse a circular no sistema. Como aponta James (1996), de um lado, havia países deficitários cuja única opção de ajuste era a promoção de políticas deflacionárias e de 
outro, países superavitários que não permitiam o crescimento da liquidez doméstica em suas economias.

Uma questão importante na relação entre a forma da divisa-chave e a liquidez internacional é a necessidade de ao mesmo tempo manter a confiança na moeda e prover liquidez ao sistema, que ficou conhecida na literatura como Dilema de Triffin. Como visto anteriormente, Cohen (2013, p. 3) afirma que a confiança é um dos fatores críticos da administração do SMI. Na definição do autor, confiança em um sentido mais amplo refere-se à manutenção da confiança nos principais instrumentos das finanças globais, basicamente as principais moedas domésticas de uso internacional. De acordo com o Dilema de Triffin, a necessidade de geração de déficits para suprir o sistema com liquidez minaria a confiança no valor da divisa-chave. Dessa forma, o sistema estaria fadado à escassez de liquidez ou à falta de confiança na divisa-chave.

Serrano (2002) contesta o Dilema de Triffin com o argumento de que, se há livre mobilidade de capitais, o emissor da divisa-chave pode fornecer liquidez sem que a confiança em sua moeda seja abalada (mesmo que essa moeda seja lastreada em ouro). Tal contestação é baseada na análise de Minsky (1994) sobre como a Inglaterra (durante parte do século XIX e início do XX) e os EUA (durante o regime de Bretton Woods) operaram o sistema de forma a prover liquidez sem incorrer em perdas de confiança. Em cada um desses regimes, o emissor da divisa-chave provia liquidez para o sistema exportando capital, mas a saída de capital de longo prazo era compensada pela entrada de fluxos de curto prazo, um mecanismo em que empréstimos de longo prazo são financiados a curto prazo. Por ser emissor da divisa-chave, espera-se que, pelo manejo da taxa de juros ${ }^{26}$, o país central do sistema seja capaz de atrair todo o financiamento desejado ("six percent can draw gold from the moon" ${ }^{27}$ ), mantendo seu estoque de ouro independentemente do tamanho do déficit de seu balanço de pagamentos. Vemos, portanto, que a assimetria do sistema (relacionada à hierarquia) se refere não apenas à capacidade quase ilimitada de atrair recursos e/ou financiar déficits, mas também de determinar a taxa de juros do sistema. Dessa forma, com livre mobilidade de capitais, o país emissor poderia aumentar a velocidade de circulação do ouro (via conta financeira) e prover liquidez ao sistema sem incorrer em um problema de confiança (Serrano, 2002). De acordo com o autor, há duas condições principais para que um mecanismo dessa natureza se sustente. A primeira é que o país não incorra em déficits persistentes em conta corrente, já que isso implicaria aumento no passivo externo líquido. A segunda é que o país não desvalorizasse sua moeda em relação ao ouro. A disposição dos agentes em deter ativos denominados nessa moeda dependeria da condição dela ser "as good as gold".

Ao constranger a emissão de divisa-chave, a conversibilidade em ouro acaba por afetar também, indiretamente, a criação de crédito nela denominado, seja no próprio país emissor,

(26) Considerando que a dívida externa do país emissor da divisa-chave tem risco zero, já que pode ser paga na própria moeda.

(27) Ditado inglês de origem incerta, popular na City londrina no início do século XX (Dornbusch; Frenkel, 1984). 
seja em centros offshore. Em centros offshore, a emissão de crédito denominado em uma moeda na qual as instituições financeiras não têm acesso ao emprestador de última instância já é um limitador. Essa restrição, no entanto, valeria igualmente em um sistema baseado em moeda fiduciária. A maior limitação de um sistema baseado em ouro é que, para a composição de reservas e o cumprimento de requisitos de liquidez, os centros offshore dependeriam do estoque de divisa-chave circulando globalmente que, por sua vez, dependeria dos estoques de ouro. No país emissor, o constrangimento à criação de liquidez via criação de crédito se daria porque o atrelamento da emissão de moeda ao ouro limitaria as funções do banco central de emprestador de última instância e provedor de liquidez no mercado de reservas bancárias.

Se a divisa-chave for puramente fiduciária, a capacidade de gerar liquidez seria ainda maior. O país emissor poderia incorrer em déficits em transações correntes de qualquer tamanho sem ter de se preocupar com o crescimento de seu passivo externo líquido, uma vez que tais obrigações poderiam ser liquidadas com a própria moeda (inconversível em ouro ou qualquer outra mercadoria). Nesse caso, a disposição dos agentes não dependeria das duas condições mencionadas acima. A demanda se daria pelo fato de a divisa-chave representar o ativo mais seguro para os detentores de riqueza.

Outro ponto importante a ser destacado é que um sistema cuja divisa-chave é lastreada em ouro (em contraposição a um em que a moeda é fiduciária) será não apenas um sistema de menor liquidez, mas, principalmente, um sistema em que há restrições no gerenciamento da liquidez internacional pelos países. Segundo Guttmann (1964), com a passagem da moedamercadoria para a moeda creditícia na década de 1930 "a regulação automática da moeda por uma mercadoria específica, imposta pelo mercado, deu lugar à regulação discricionária, comandada pelo Estado." (Ibid, 1996, p. 54). Ou seja, sem o ouro como fator de restrição, os países (no caso o país emissor da divisa-chave) passaram a ter maior controle sobre a liquidez internacional; esta tornou-se uma variável passível de controle.

Sistemas mais elásticos e com maior liquidez internacional tendem a tornar menos custoso o processo de ajustamento externo dos países (especialmente os periféricos) e proporcionar um SMI com orientação mais expansionista, embora também haja o risco de ser mais instável, dada a possibilidade de grandes oscilações na liquidez internacional ${ }^{28}$. Daí decorre a importância do gerenciamento público ou cooperativo da liquidez internacional.

A proposta de Keynes de criação da União Internacional de Compensações (UCI) é um bom exemplo de como a elasticidade do sistema poderia operar a favor de um sistema mais expansionista. A UCI seria justamente uma forma de aliviar o constrangimento proporcionado

(28) Como mostrado por Thirwall e Hussain (1982) em seus estudos da relação entre crescimento econômico e restrição externa, a livre mobilidade de capitais pode relaxar a relação entre equilíbrio do BOP e absorção doméstica, proporcionando outros mecanismos de ajustamento que não a contração da renda. No entanto, a condição necessária para isso seria o crescimento permanente dos fluxos de capitais para o país. Dessa forma, o principal fator de restrição ao crescimento econômico deixaria de ser a relação entre exportações e importações (a chamada Lei de Thirwall) e passaria a ser não apenas a continuidade, mas uma taxa positiva de crescimento dos fluxos de capitais (Ibid, p. 504). 
pelos estoques de ouro sobre a liquidez internacional. Keynes propunha que a UCI e a emissão da divisa-chave (que ele chamava de moeda mundial - world currency), o bancor, funcionassem à semelhança de um sistema bancário, ou seja, o bancor funcionaria como uma moeda bancária. O saldo superavitário dos países seria mantido como um saldo credor pela UCI e poderia ser usado como forma de financiar aqueles com saldo deficitário, embora ainda permanecendo disponível para seu detentor. Não seria um mecanismo de empréstimo compulsório e sim algo próximo de um sistema bancário, em que saldos ociosos são emprestados pela instituição, dando mais liquidez ao sistema. Era uma forma de levar ao SMI a elasticidade que o sistema bancário dava aos sistemas monetários e financeiros nacionais e que funcionavam como poderoso instrumento de desenvolvimento econômico.

(...) the fact that the creditor country is not choosing to employ this purchasing power would not mean, as it does at present, that it is withdrawn from circulation and exerts a deflationary and contractionist pressure on the whole world including the creditor country itself. (...)Just as the development of national banking systems served to offset a deflationary pressure which would have prevented otherwise the development of modern industry, so by carrying this analogy into the international field we may hope to offset the contractionist pressure which might otherwise overwhelm in social disorder and disappointment the good hopes of our modern world (Keynes, 1980/2013, p. 177).

Pela sua proposta, o papel do ouro nos sistemas financeiros domésticos ficaria a cargo das decisões de cada país, mas seu papel no SMI seria reduzido. Uma das características mais importantes a ser destacada na UCI é que o volume da divisa-chave não estaria atrelado ao volume de ouro. Esta desvinculação seria possível porque o bancor teria uma "conversibilidade de mão única", podendo ser comprado com ouro, mas sem poder ser utilizado para adquirir o mesmo. Dessa forma, o ouro não seria mais um constrangimento. Em suas palavras: "The quantity of bancor was absolutely elastic" (Keynes, 1980/2013, p. 140).

Keynes defendia que o volume da divisa-chave deveria ser uma variável administrável e não determinada de maneira imprevisível (pelo progresso técnico do processo de mineração aurífera, por exemplo) e sujeito à política de administração de reservas dos grandes detentores do metal. Ao invés de estar sujeita a fatores exógenos, a liquidez internacional deveria ser determinada de acordo com o que se julgasse necessário ao desenvolvimento do comércio internacional e de forma a contrair e expandir o sistema visando deliberadamente eliminar pressões inflacionárias e deflacionárias na demanda efetiva mundial. Segundo Wray (2001), uma instituição como a proposta por Keynes e Davidson ${ }^{29}$ não apenas teria o benefício de tornar o sistema mais elástico, mas seu caráter público também é fundamental, pois em um sistema "administrado/gerenciado" por instituições privadas buscando o lucro, a função de marketmaker e de garantia da estabilidade das taxas de câmbio poderia conflitar com interesses próprios.

(29) Ver Davidson (1997). 
Divisa-chave, elasticidade, liquidez internacional e autonomia de política econômica no Sistema ...

Atualmente, o mais próximo que se tem da proposta defendida por Keynes é a utilização do DES. Seu emprego foi proposto pela China em reunião do Brics que antecedeu a cúpula de Londres de 2009 do G20 ${ }^{30}$. Xiaochuan ${ }^{31}$ (2009) defende que uma moeda de reserva internacional deve apresentar três características essenciais, quais sejam: i) ser uma referência estável e regida por regras claras; ii) ter uma oferta suficientemente elástica para atender alterações na demanda; e iii) tais ajustamentos devem ser independentes das condições econômicas e interesses soberanos de países específicos. Sendo assim, tais condições se assemelham aos aspectos defendidos por Keynes. Como o dólar não se enquadraria no primeiro e terceiro aspecto e nem sempre no segundo, o autor defende a utilização do DES, o qual estaria sendo subutilizado. Como vantagens, ele não apenas eliminaria os riscos de uma moeda baseada no crédito como também tornaria possível gerir a liquidez global. Por consequência, os países teriam uma melhor capacidade de gerir suas moedas a fim de evitar crises futuras.

\section{Autonomia de política econômica e o SMI}

Tendo analisado como a autonomia de política econômica pode ser fortalecida ou reduzida no SMI a partir de seus elementos constitutivos, o próximo passo é tratar da sua importância e implicação para os diferentes agentes e para a orientação do SMI. Não há muita controvérsia na ideia geral de que a autonomia é enfraquecida em certas circunstâncias, especialmente na presença de alta mobilidade de capitais. A divergência ocorre em relação aos benefícios ou malefícios de tal redução.

Para autores como Fischer (1998) e Eichengreen (2001), uma menor autonomia poderia ser uma boa maneira de disciplinar os governos. A ideia é que a alocação de recursos por investidores privados seria guiada pela qualidade das políticas praticadas, de forma que aquelas "irresponsáveis" seriam punidas com a fuga de capitais e as "responsáveis" premiadas pelas entradas de capitais. Aqui há a hipótese implícita de que a dinâmica dos fluxos de capitais estaria ligada diretamente a fatores internos, ou seja, à qualidade das políticas domésticas. Fugas de capitais, portanto, não seriam causadas pela abertura financeira em si, mas pela adoção de políticas equivocadas (ou irresponsáveis). Por isso, de acordo com essa visão, os formuladores de políticas não seriam tão entusiastas da disciplina imposta pelos mercados. Para Eichengreen (2001), os mecanismos e instrumentos usados para fortalecer a autonomia seriam

(30) O G-20 é formado por África do Sul, Alemanha, Arábia Saudita, Argentina, Austrália, Brasil, Canadá, China, Coréia do Sul, Estados Unidos, França, Índia, Indonésia, Itália, Japão, México, Reino Unido, Rússia, Turquia e União Europeia (Comissão Europeia, Presidência e Banco Central Europeu). O grupo foi criado em 1999 com intuito de discutir soluções e buscar uma maior cooperação após as crises nos balanços de pagamentos dos países emergentes na década de 1990. Após empenho de alguns países, em especial Brasil e China, o G20 passou a se tornar o principal fórum para as decisões internacionais. Tal como afirma Cunha (2009): “As reuniões de cúpula do G7 (ampliado com a Rússia, no chamado G8) perderam importância relativa, em linha com a própria mudança na estrutura da geoeconomia mundial. O G20, com os Brics [Brasil, Rússia, Índia e China], passou a ser o espaço de maior poder gravitacional para a discussão das reformas de caráter estrutural, bem como da tentativa de coordenação nas políticas de crédito e fiscais" (Cunha, 2009, p. 12). Essa mudança de patamar também pode ser observada pelo fato de que a partir de 2009 o G20 deixou de ser um fórum de Ministros da Fazenda e Presidentes de Bancos Centrais para ser uma Cúpula de Líderes dos seus respectivos países.

(31) Presidente do Banco do Povo da China, o Banco Central Chinês. 
apenas uma maneira dos governos não enfrentarem os verdadeiros problemas causadores das crises, especialmente os "excessos" nas políticas monetária e fiscal.

Para Carvalho (2004) a defesa de tal sistema pode ser explicada pela crença na hipótese dos mercados eficientes (HME), segundo a qual o livre funcionamento dos mercados promove uma eficiente alocação de recursos. De acordo com a lógica da HME, as preferências explicitadas pelo comportamento dos mercados podem levar o governo a adotar melhores políticas. No entanto, as políticas vistas como melhores, mais responsáveis ou mais eficientes geralmente são as de cunho restritivo. Assim, para manter a confiança dos investidores privados, essas são as políticas que os países teriam de adotar (Belluzzo, 2000).

É preciso levar em consideração que os investidores privados têm como meta principal a rentabilidade e a segurança de seus investimentos e é sob esse prisma que eles tomam suas decisões acerca da alocação mais eficiente do estoque de riqueza. Uma de suas maiores preocupações é ter um ambiente seguro e estável para investimentos (o que pode ajudar a explicar o grande valor dado à baixa inflação). Portanto, uma vez que a HME é deixada de lado, não há razão para supor que os interesses dos investidores privados serão necessariamente coincidentes com os interesses dos Estados. Como diz Rodrik (1998, p. 11) "We would have to have blind faith in the efficiency of rationality of international capital markets to believe that the goals of foreign investors and of economic development will regularly coincide."

Assim, a questão da autonomia é, em última instância, uma decisão sobre relações de poder dentro do SMI. Em outras palavras, quem terá mais poder: os mercados, para constranger as opções de política, ou os governos, para garantir a autonomia necessária à adoção das políticas desejadas? No primeiro caso, poderíamos ter um sistema mais restritivo, com a adoção predominante de políticas restritivas e, no segundo, haveria mais espaço para políticas expansionistas e anticíclicas.

Retomando a questão do trilema, não apenas é contestável a ideia de que com mobilidade de capitais é possível ter autonomia de política monetária (independentemente do regime cambial), como a afirmação de que há um trade-off entre taxas estáveis de câmbio, livre mobilidade de capitais e autonomia de política monetária traz implícita a ideia de que esses três elementos são desejáveis. Pode-se considerar que a importância da estabilidade da taxa de câmbio seja um consenso, mas não os dois outros elementos. Assim, a ideia da trindade impossível de que é preciso "sacrificar" um dos elementos para se obter os outros dois só faz sentido se considerarmos que todos são desejáveis. Aí, de fato, temos um trilema, uma situação em que é preciso escolher entre alternativas desejáveis. Em contraposição aos autores favoráveis à HME, as propostas de Keynes (1984) mostram claramente a opção por sacrificar a mobilidade em nome da autonomia: “(...) pretendemos reter o controle de nossa taxa interna de juros, a fim de mantê-la tão baixa quanto convier a nossos propósitos, sem a interferência dos fluxos e refluxos dos movimentos internacionais de capitais ou das fugas de dinheiro vivo." (Ibid, p. 213). 
A partir do momento em que a mobilidade de capitais não é considerada benéfica (ou um fim em si mesma), a decisão recairia sobre o vértice que concilia estabilidade cambial e autonomia, não havendo, portanto, qualquer conflito entre opções desejáveis, ou "trilema".

Como no caso da autonomia de política econômica, em um sistema em que as fontes de recursos são prioritariamente fluxos privados de capital, os investidores e instituições financeiras ganham poder dentro do sistema e terão poder de barganha sobre os governos. Portanto, um SMI com alta mobilidade de capitais é um sistema em que os mercados financeiros têm poder sobre governos pela movimentação de recursos constante, rápida e com baixo custo, o que constrange a autonomia de política dos governos, que têm que se adaptar às preferências dos mercados, e tornam o sistema mais instável.

Se o preço da integração financeira internacional é o fortalecimento de um regime de alto desemprego e baixo crescimento imposto aos países devedores, esperamos então que medidas para o estabelecimento de maior autonomia da política econômica dos estados nacionais venham a estar novamente na agenda da política (Minsky, 1994, p. 34).

Mas, se houver cooperação, a provisão de recursos entre países e entre países e instituições internacionais pode ser um instrumento para reduzir o poder do MFI, o que exige um mínimo de coordenação e harmonia em torno do que são consideradas políticas adequadas. Há que se considerar também todas as dificuldades em se construir acordos e mecanismos de cooperação, que dependem da aceitação de outros países ${ }^{32}$ e que podem levar muito tempo para entrar em vigor, o que faz com que em alguns momentos as soluções individuais sejam as únicas disponíveis.

Em geral, governos requerem um conjunto mínimo de condições para emprestar dinheiro a outros. Afinal, tais empréstimos são sempre, de algum modo, constrangidos pelas condições políticas domésticas. O mesmo vale para as instituições internacionais. Estas podem ser uma fonte adicional de recursos aos países, mas, mesmo que reconheçam a importância da autonomia para os países, algumas condições mínimas têm de prevalecer. Ou seja, mesmo com os potenciais benefícios mencionados, instituições internacionais e mecanismos de cooperação também restringem a autonomia dos governos. O importante é que se garanta que essa restrição seja de natureza diferente da exercida pelos MFIs.

Investidores e gestores de recursos tendem a preferir políticas que priorizem a geração de um ambiente estável e seguro para os investimentos financeiros, mas as preferências dos países e instituições financeiras variam de acordo com o que são consideradas políticas responsáveis em diferentes épocas. $\mathrm{O}$ fator a ser destacado aqui é que quando países e instituições internacionais são os agentes de constrangimento, as condicionalidades de acesso a recursos pelos países devedores podem e tendem a ser diferentes daquelas requeridas pelo

(32) Sempre constrangidos por forças políticas domésticas e estrangeiras e sujeito a mudanças de governos que possam colocar em risco negociações e acordos em andamento. 
MFI. Além disso, razões estratégicas ou de urgência podem fazer com que essas condicionalidades por parte de países e instituições sejam ainda mais relaxadas.

Ainda em relação à liquidez internacional e à elasticidade, estas são variáveis fundamentais para dar potencial de crescimento ao sistema e para facilitar (ou dificultar) o acesso de outros países às moedas conversíveis e à divisa-chave. Em outras palavras, ambas variáveis seriam importantes para proporcionar mecanismos expansionistas para o ajuste do balanço de pagamentos, especialmente para os países periféricos, que são ainda mais dependentes dos ciclos internacionais de liquidez. Por isso, é tão importante um sistema em que tais variáveis possam ser manejadas por formuladores de políticas e não sejam dependentes apenas de condições de mercado, ainda que, como aponta Fiori (2005), o país central do sistema - que ele chama de hegemon - possa utilizar de seu poder para obter benefícios próprios, prejudicando não apenas outros países, mas o próprio sistema.

\section{Considerações finais}

O objetivo do artigo foi fazer uma relação entre a autonomia de política econômica e os elementos componentes do SMI, com foco na relação entre autonomia e divisa-chave. A partir dos conceitos de moeda conversível e inconversível, mostrou-se que a hierarquia de moedas vigente leva a uma assimetria que se revela no maior constrangimento de política econômica dos países periféricos em relação aos centrais.

Do mesmo modo, buscou-se ir além da questão da conversibilidade da moeda e analisar de que forma um sistema mais elástico, que permita um maior crescimento da liquidez internacional, pode reduzir a assimetria entre países periféricos e centrais, fortalecendo a autonomia até mesmo dos países periféricos. A preocupação fundamental é propiciar aos países mecanismos de ajuste outros que não os deflacionários ou recessivos. Nesse ínterim, um sistema mais elástico é necessário, mas não suficiente. Faz-se mister também que o funcionamento do sistema e a administração de suas principais variáveis (elasticidade e liquidez entre elas) tenha um caráter mais público/cooperativo, de forma que estas não dependessem tanto de decisões privadas. Em outras palavras, que as questões monetárias internacionais sejam determinadas menos pelo SFI e mais pela cooperação entre governos e instituições internacionais.

Essa foi uma preocupação de Keynes no regime de Bretton Woods, mas que nunca pôde ser efetivamente colocada em prática. Isso reflete os obstáculos políticos de tal tarefa e da implementação de um sistema em que haja menor assimetria e cujo gerenciamento possa ter um caráter mais público/cooperativo. Tais obstáculos refletem não apenas conflitos entre diferentes segmentos da sociedade, como também entre Estados buscando sistemas com orientações distintas. Países da área do euro, Inglaterra e principalmente os EUA não gostariam de ver suas moedas perdendo em importância no cenário internacional. Estes países também contariam com o apoio dos grandes grupos financeiros internacionais que veriam reduzidas as possibilidades de ganhos especulativos em um sistema monetário e financeiro internacional mais estável e regulado. 
Levando-se em conta as implicações políticas que o SMI pode ter para os diferentes agentes que nele operam, faz-se imperativo o estudo da formação e da estabilidade do SMI a partir de um arcabouço que considere os aspectos políticos de tais processos. O SMI nunca é neutro, ou seja, sua configuração, olhada a partir das diferentes combinações de seus componentes fundamentais, sempre operaria de forma a reproduzir uma ideologia, uma visão de como deve ser a dinâmica econômica e o poder dos diferentes agentes dentro do sistema. Para Strange (1996, p. 22), o sistema sempre operaria de forma a beneficiar alguns países e a priorizar certos valores sociais em detrimento de outros. Sendo a maior ou menor autonomia no SMI uma questão política, o processo de construção do SMI também tem de ser visto desta perspectiva, ou seja, a definição dos elementos e da configuração do SMI será sempre alvo de disputas de forma a definir quem terá poder no sistema. Dentro dessa perspectiva, o estudo da Economia Política Internacional é um importante campo a ser explorado para compreender as possibilidades de alterações substantivas no SMI.

\section{Referências bibliográficas}

ARRIGHI, G. The long twentieth century - money, power and the origins of our times. London, New York: Verso, 1994.

BANERJEE, A. V. A simple model of herd behavior. The Quarterly Journal of Economics, v. 107, n. 3, p. 797-817, Aug. 1992.

BELLUZZO, L. G. M. Finança global e ciclos de expansão. In: FIORI, J. L (Org.). Estados e moedas no desenvolvimento das nações. 3. ed. Petrópolis: Vozes, 2000.

BELlUZZO, L. G.; CARNEIRO, R. O mito da conversibilidade. Revista de Economia Política, v. 24, n. 2, abr./jun. 2004.

BIANCARELLI, A. M. Integração, ciclos e finanças domésticas: o Brasil na globalização financeira. Tese (Doutorado)-Instituto de Economia, Universidade Estadual de Campinas, Campinas, 2007.

BORIO, C.; DISYATAT, P. Global imbalances and the financial crisis: link or no link? BIS Working Papers, n. 346, 2011.

BRADFORD, C. I. Prioritizing economic growth: enhancing macroeconomic policy choice. G-24 1999. (Discussion Paper Series, 2005). Disponível em: http://www.unctad.org/en/docs/gdsmdpbg2420054_en.pdf. Acesso em: 20 dez. 2007.

CALVO, G. A.; MENDOZA, E. G. Rational contagion and the globalization of securities markets. NBER Working Paper, n. 7153, 1999.

CARNEIRO, R. A política macroeconômica da era FHC ao governo Lula: da trindade impossível à autonomia necessária. In: VELLOSO, J. P. R. (Coord.). Governo Lula: novas prioridades. Rio de Janeiro: J. Olympio, 2003. 
CARNEIRO, R. Globalização e inconversibilidade monetária. Revista de Economia Política, v. 28, n. 4 (112), p. 539-556, out./dez. 2008.

CARVALHO, F. J. C. Controles de capitais: uma agenda de pesquisa. Revista de Economia Contemporânea, v. 8, n. 2, p. 283-298, 2004.

COHEN, B. The geography of money. Cornell University Press, 2004.

COHEN, B. Global turmoil: the international monetary system today. The Brics and Asia, Currency Internationalization and International Monetary Reform. Paper, n. 1, June, 2013. Disponível em: http://issuu.com/cigi/docs/brics_asia_no1/1?e=0. Acesso em: 5 jul. 2013.

COUTINHO, L.; BELlUZZO, L. G. Desenvolvimento e estabilização sob finanças globalizadas. Economia e Sociedade, Campinas, n. 7, p. 129-154, 1996.

DAVIDSON, P. Are grains of sand in the wheels of international finance sufficient to do the job when boulders are often required? The Economic Journal, v. 107, n. 442, p. 671-686, May 1997.

DAVIDSON, P. The case for regulating international capital flows. Trabalho apresentado no Seminário sobre a Regulação dos Movimentos de Capitais. Social Market Foundation. London, 17 Nov. 1998. Disponível em: http://econ.bus.utk.edu/faculty/davidson/reg2.pdf. Acesso em: 3 set. 2008.

DE CONTI, B. M. Políticas cambial e monetária: os dilemas enfrentados por países emissores de moedas periféricas. Tese (Doutorado)-Instituto de Economia, Universidade Estadual de Campinas, Campinas, 2011.

DORNBUSCH, R.; FRENKEL, J. A. The gold standard and the bank of England in the crisis of 1847. In: BORDO, M. D.; SCHWARTZ, A. J. (Ed.). A retrospective on the classical gold standard, 1821-1931. 1984. Disponível em: http://www.nber.org/chapters/c11130.

DOW, S. C. International liquidity preference and endogenous credit. In: DEPREZ, J.; HARVEY, J. T. (Ed.). Foundations of international economics post Keynesian perspectives. London: Routledge, 2001.

EICHENGREEN, B. International policy coordination in historical perspective: a view from the interwar years. In: BUITER, W. H.; MARSTON, R. C. International economic policy coordination. Cambridge University Press. 1985. Disponível em: http://www.nber.org/chapters/c4134. Acesso em: 14 jun. 2012.

EICHENGREEN, B. Capital account liberalization: what do cross-country studies tell us? The World Bank Economic Review, v. 15, p. 341-365, 2001.

EICHENGREEN, B.; FLANDREAU, M. The rise and fall of the dollar (or when did the dollar replace sterling as the leading reserve currency?). European Review of Economic History, v. 13, p. 377-411, 2009. 
Divisa-chave, elasticidade, liquidez internacional e autonomia de política econômica no Sistema ...

EICHENGREEN, B.; HAUSMANN, R.; PANIZZA, U. The pain of original sin. 2003. Disponível em: http://www.econ.berkeley.edu/ eichengr/research/ospainaug21-03.pdf. Acesso em: 29 jan. 2009.

FARHI, M. O impacto dos ciclos de liquidez no Brasil: mercados financeiros, taxa de câmbio, preços e política monetária. Boletim Semestral do Centro de Estudos de Conjuntura e Política Econômica do Instituto de Economia da Unicamp, nov. 2005 / abr. 2006.

FEDERAL RESERVE BOARD (FED). Federal Reserve Bulletin, June. 1922. Disponível em: http://fraser.stlouisfed.org/docs/publications/FRB/1920s/frb 061922.pdf. Acesso em: 3 ago. 2012.

FINK, C. The Genoa Conference. Chapel Hill; London: University of North Carolina Press, 1984.

FIORI, J. L. Formação, expansão e limites do poder global. In: FIORI, J. L (Org.). O poder americano. 2. ed. Petrópolis: Vozes, 2005.

FISCHER, S. Capital account liberalization and the role of the IMF. Essays in International Finance, Princeton, n. 207, 1998.

FLASSBECK, H. The exchange rate: economic policy tool or market price? Unctad Discussion Papers, n. 157, Nov. 2001. Disponível em: http://www.unctad.org/en/docs/dp 157.en.pdf. Acesso em: 21 out. 2007.

GALLAGHER, K. P.; GRIFFITH-JONES, S.; OCAMPO, J. A. Capital account regulations for stability and development: a new approach. In: GALLAGHER, K. P.; GRIFFITH-JONES, S.; OCAMPO, J. A. (Org.). Regulating global capital flows for long-run development. Pardee Center Task Force Report. 2012. Disponível em: http://www.bu.edu/pardee/files/2012/03/RegulatingCapitalTF-March2012.pdf. Acesso em: abr. 2013.

GUTTMANN, R. A transformação do capital financeiro. Economia e Sociedade, Campinas, v. 7, p. 51-83, dez. 1996.

INTERNATIONAL MONETARY FUND (IMF). Articles of agreement of the International Monetary Fund, 2011.

JAMES, H. International monetary cooperation since Bretton Woods. Washington, D.C.: International Monetary Fund / New York, Oxford: Oxford University Press, 1996.

JAMES. H. International cooperation and central banks. Essays on International Finance, v. 1, Out. 2013. Disponível em: https://www.cigionline.org/sites/default/files/vol.1.pdf. Acesso em: 1 jul. 2014.

KEYNES, J. M. The general theory and after. In: MOGGRIDGE, D.; JOHNSON, E. The collecting writings of John Maynard Keynes, v. XXIX. Macmillan Cambridge University Press, 1978. 
Adriano Vilela Sampaio, Maurício Andrade Weiss

KEYNES, J. M. A união internacional de compensação. In: SZMRECSÁNYI, T. (Org.). Keynes. 2. ed. São Paulo: Ática, 1984.

KEYNES, J. M. A teoria geral do emprego, do juro e da moeda. São Paulo: Nova cultural, 1996.

KEYNES, J. M. (1980/2013). Activities 1940-1944 Shaping the post-war world: The Clearing Union, 1980. In: MOGGRIDGE, D. The collected writings of John Maynard Keynes, v. XXV. Cambridge: Cambridge University Press, 2013.

KEYNES, J. M. (1930/2013). A treatise on money, 1930. In: MOGGRIDGE, D. The collected writings of John Maynard Keynes, v. V. Cambridge: Cambridge University Press, 2013.

MENDONÇA, H. F.; PIRES, M. C. C. Liberalização da conta de capitais e inflação: a experiência brasileira no período pós-real. Revista Estudos Econômicos, v. 36, n. 1, p. 149179, jan./mar. 2006.

MINSKY, H. Integração financeira e política monetária. Economia e Sociedade, Campinas, n. 3, dez. 1994.

MUNDELL, R. A. Capital mobility and stabilization policy under fixed and flexible exchange rates. The Canadian Journal of Economics and political science, v. 29, n. 4, Nov. 1963.

PRATES, D. M. Investimentos de portfólio no mercado financeiro doméstico. In: FREITAS, Maria Cristina P. (Org.). Abertura do sistema financeiro no Brasil. São Paulo: Fundap/Fapesp; Brasília: Ipea, 1999.

PRATES, D. M. Crises financeiras dos países "emergentes": uma interpretação heterodoxa. Tese (Doutorado)-Instituto de Economia, Universidade Estadual de Campinas, Campinas, 2002 .

REY, H. Dilemma not trilemma: the global financial cycle and monetary policy independence. London Business School: CEPR and NBER, Aug. 2013.

RODRIK, D. Who needs capital-account convertibility? Essays in International Finance, Princeton, n. 207, p. 55-65, 1998.

SAMPAIO, A. V. Sistema Monetário Internacional em uma perspectiva de economia política internacional: estratégias dos países periféricos nas décadas de 1990 e 2000. Tese (Doutorado em Economia)-Instituto de Economia, Universidade Estadual de Campinas, Campinas, 2014.

SERRANO, F. Do ouro imóvel ao dólar flexível. Economia e Sociedade, Campinas, v. 11, n. 2 (19), p. 237-253, jul./dez. 1998.

STRANGE, S. The retreat of the state. The diffusion of power in the world economy. Cambridge: Cambridge University Press, 1996. 
Divisa-chave, elasticidade, liquidez internacional e autonomia de política econômica no Sistema ...

TAKÁTS, E.; VELA, A. International monetary policy transmission. In: BANK FOR INTERNATIONAL SETTLEMENTS. The transmission of unconventional monetary policy to the emerging markets. BIS Papers, n. 78, p. 25-44, 2014.

THIRLWALL, A.; HUSSAIN, M. N. The balance of payments constraint, capital flows and growth rate differences between developing countries. Oxford Economic papers, v. 34, n. 3, p. 498-510, Nov. 1982.

TOBIN, J. A proposal for international monetary reform. Eastern Economic Journal, v. 4, p.153-159, 1978. Disponível em: http://college.holycross.edu/eej/Volume4/V4N3 4P153_159.pdf. Acesso em 20 jul. 2007

XIAOCHUAN, Z. Essay by Dr Zhou Xiaochuan, Governor of the People's Bank of China, 23 March 2009. Disponível em: http://www.bis.org/review/r090402c.pdf. Acesso em: 14 dez. 2013.

WILLIAMSON, J. Getting surplus countries to adjust. Policy brief. Peterson Institute for International Economics. 2011. Disponível em: http://www.iie.com/publications/pb/pb1101.pdf. Acesso em: 20 abr. 2013.

WRAY, L. R. The development and reform of the modern international monetary system. In: DEPREZ, J.; HARVEY, J. T. (Ed.). Foundations of international economics Post Keynesian perspectives. London: Routledge, 2011. 